\title{
In situ variation in leaf anatomy and morphology of Andira legalis (Leguminosae) in two neighbouring but contrasting light environments in a Brazilian sandy coastal plain
}

\author{
Daniela Carvalho Pereira ${ }^{1,2}$, Cláudia Franca Barros ${ }^{2}$ and Fabio Rubio Scarano
}

Recceived: September 24, 2007. Accepted: August 11, 2008

\begin{abstract}
RESUMO - (Variação in situ em anatomia e morfologia foliar de Andira legalis (Leguminosae) em dois ambientes adjacentes, porém contrastantes quanto ao regime de luz, em restinga brasileira). Andira legalis (Vell.) Toledo é uma leguminosa arbustiva distribuída ao longo de planícies arenosas da costa brasileira. Tem ocorrência em ambientes florestais, sombreadas, ou em ilhas de vegetação de restingas abertas, onde é exposta à plena radiação solar. Estudos prévios relataram uma grande amplitude de variação morfo-fisiológica para esta espécie ao longo de um gradiente geográfico. Este estudo comparou morfologia e anatomia foliar de A. legalis em dois ambientes adjacentes porém contrastantes quanto ao regime de luz: uma floresta densa (sombreada) e uma formação arbustiva de Palmae (exposta à luz). Estudamos a amplitude de variação morfo-anatômica no interior de uma diminuta dimensão geográfica $(0,5$ ha). Parâmetros de anatomia foliar foram medidos para cinco folhas coletadas a partir de cinco plantas em cada habitat. Os parâmetros avaliados foram: espessura foliar e do mesofilo, espessura da parede celular periclinal externa, espessura adaxial e abaxial da epiderme, área da seção transversal do feixe vascular, e densidade de células epidérmicas comuns, estômatos e tricomas. Dados de morfologia foliar foram obtidos a partir de cinco folhas de cada uma de 20 plantas em cada sítio. Medidas de peso seco e fresco foram tomadas para a obtenção dos valores de massa específica foliar e suculência. Conforme era esperado, os valores de todos os parâmetros anatômicos e morfológicos, exceto densidade de tricomas, foram significativamente mais altos para as plantas expostas ao sol. Menos esperado, entretanto, foi a clara diferença qualitativa entre folhas de plantas expostas vs. sombreadas: nas expostas, o mesofilo apresentou simetria unilateral (i.e., todo o mesofilo era ocupado por tecido fotossintético), enquanto nas sombreadas a simetria foi dorsiventral (i.e., em parte parênquima paliçádico, em parte parênquima esponjoso). Tal amplitude de variação mostra que, mesmo em uma pequena área geográfica, A. legalis tem uma ampla plasticidade ecológica.
\end{abstract}

Palavras-chave: anatomia foliar, Andira legalis, floresta atlântica, plantas de sol e sombra, restinga

\begin{abstract}
In situ variation in leaf anatomy and morphology of Andira legalis (Leguminosae) in two neighbouring but contrasting light environments in a Brazilian sandy coastal plain). Andira legalis (Vell.) Toledo is a legume shrub widespread along the sandy plains of the Brazilian coast. It occurs both shaded, in forest habitats, or exposed to full sunlight, in the vegetation islands growing on sand deposits. Previous studies reported a high range of morpho-physiological variation for this species along a geographical gradient. This study compared leaf morphology and anatomy of A. legalis in two distinct but adjacent light environments: a dense forest (shaded) and a scrub of Palmae (exposed). We studied the amplitude of variation for these traits within a small (0.5 ha) geographical area. Leaf anatomy parameters were measured for five leaves collected from five plants in each habitat. The parameters measured were leaf and mesophyll thickness, thickness of the outer periclinal cell wall, thickness of the adaxial and abaxial epidermis and vascular bundle transversal section area, and also common epidermal cells, stomata and trichome density. Leaf morphology parameters were obtained from five leaves of each of 20 plants in each site. Dry and fresh weights were measured to obtain leaf specific mass and succulence. All anatomy and morphology parameters, except trichome density, were significantly higher for the sun-exposed plants. Less expected, however, was the marked qualitative difference between exposed and shaded plants: in the former the mesophyll had a unilateral symmetry (i.e., the whole mesophyll occupied by photosynthetic tissue), whereas in the latter there was a dorsiventral symmetry (i.e., partly palisade and partly spongy parenchyma). Such amplitude of variation shows that even within a small geographic area A. legalis has a broad ecological plasticity.
\end{abstract}

Key words: Andira legalis, Atlantic forest, leaf anatomy, restinga, sun-shade plants

\section{Introduction}

The Brazilian Atlantic forest complex is formed by different vegetation physiognomies (Rizzini 1979). In the montane forest, at the core of the complex, lies the highest species diversity and endemism. In contrast, the plant communities at the periphery of this forest are less structurally complex and are often less species diverse

\footnotetext{
1 Universidade Federal do Rio de Janeiro, CCS, IB, Departamento de Ecologia, C. Postal 68020, 21941-590 Rio de Janeiro, RJ, Brazil

2 Instituto de Pesquisas Jardim Botânico do Rio de Janeiro, Diretoria de Pesquisas Científicas, Rua Pacheco Leão 915, $22460-000$ Rio de Janeiro, RJ, Brazil

3 Corresponding author: fscarano@biologia.ufrj.br
} 
(Scarano 2002). One of these marginal habitats, called locally restinga, covers the sandy coastal plains of Brazil. This ecosystem is a mosaic of habitats, ranging from reptant beach vegetation to swamps, which collectively subject plants to more extreme environment conditions than the mesic montane forest, such as salinity, flooding, drought or heat (Lacerda et al. 1993). However, most plant species inhabiting the restingas originated in the montane forest (Rizzini 1979; Scarano 2002) and, thus, had the capacity to adjust and colonize this more severe environment. This ability might be the result of ecological advantage obtained by morpho-anatomical (Rôças et al. 2001) and physiological (Scarano et al. 2001; 2005; Duarte et al. 2005) modifications.

In restingas, although different communities frequently lie adjacent to each other (Lacerda et al. 1993), very few plants occur in more than one or two habitats. Andira legalis (Vell.) Toledo (LeguminosaePapilionoidae) is one such plant. In the case studied here, light levels change abruptly between a forest and an adjacent open shrubland. In this ecotone, there is no transitional vegetation between these two contrasting formations (Cirne \& Scarano 2001). Sun and shade Andira legalis occur within a few meters distance from each other. However, in previous studies we found marked differences between sun and shade plants. For instance, sun plants are short (1.5 m of height) and invest highly in wide underground organs from where numerous ramets emerge, whereas shade plants are taller (up to $5.0 \mathrm{~m}$ tall), not so conspicuous and clonal growth is not apparent (Cirne \& Scarano 2001). Sun plants have negative spatial association with other local shrubs and herbs, suggesting a competitive effect, whereas no such pattern is found for the shade plants (Cirne et al. 2003). Finally, sun plants nodulate and fixate nitrogen, unlike shade plants (Scarano et al. 2001; Geßler et al. 2005).

In this study, we examined to which extent this large architectural, physiological and ecological variation between neighbouring plants under contrasting light regimes is matched by variation in leaf anatomy and morphology. It is well known that most plant species have the ability to develop distinct leaves when growing under distinct light levels (Ashton \& Berlyn 1992; Chazdon \& Kaufmann 1993; Lee et al. 2000; NúñezOliveira et al. 1996; Strauss-Benedetti \& Berlyn 1994), and wide variation has been described to several species of the Brazilian Atlantic forest complex subjected to sunshade extremes (Scarano et al. 1999; 2002; Rôças et al. 2001; Mantuano et al. 2006). However, most such studies were either set in the laboratory or in the field covering broad geographic ranges. Here leaf variation in anatomy and morphology for Andira legalis is examined for plants in two adjacent habitats (sun vs. shade), however within only a few meters of distance from each other.

\section{Materials and methods}

Study site and studied species - Samples were collected in the Jacarepiá State Ecological Reserve, in the municipality of Saquarema, on the northern coast of Rio de Janeiro state, southeastern Brazil (22 $47^{\circ}-22^{\circ} 57^{\prime} \mathrm{S}$ and $42^{\circ} 20^{\prime}-42^{\circ} 43^{\prime} \mathrm{W}$ ). Mean annual rainfall is $1000 \mathrm{~mm}$ and mean annual temperature ranges from 24 to $26^{\circ} \mathrm{C}$. The swale between forest and strand line is covered by marsh vegetation dominated by Graminae and Cyperaceae, except where a spit of sandy soil, some $200 \mathrm{~m}$ long by $70 \mathrm{~m}$ wide (maximum) extends from the forest edge almost to the beach. The spit vegetation shows a striking dominance of the legume shrub Andira legalis (Vell.) Toledo and the geophyte palm Allagoptera arenaria (Gomes) O. Kuntz. There is no transitional zone between the forest, where A. legalis is less abundant, and the open shrubland. Thus, Andira plants from forest or shrubland, which are closest to the border between the two habitats, are ca. 20-30 m far from each other. Nevertheless, light regime changes abruptly from one formation to the other. Measurements of photosynthetic active radiation (PAR) for both sites $\left(5-50 \mu \mathrm{E} \mathrm{m}^{-2} \mathrm{~s}^{-1}\right.$ for the dry forest and $1500-2000 \mu \mathrm{E} \mathrm{m}^{-2} \mathrm{~s}^{-1}$ for the spit) showed clearly the light distinctions between them (Cirne \& Scarano 2001; Scarano et al. 2001; 2002; Cirne et al. 2003).

The genus Andira A.L. Jussieu has 29 Neotropical species, with two subspecies occurring in Africa (Pennington \& Gemeinholzer 2000). Andira legalis is a legume shrub restricted to the coastal vegetation from southeast to northeast Brazil (Mattos 1979), occurring in both exposed (open shrubby vegetation in the sandy coastal plain) and shaded environments (in coastal or low montane forest). Contrasting with the majority of the species in the genus, it has big fruits that are probably dispersed by large rodents (Pennington \& Gemeinholzer 2000). Although some fruit production has taken place, seedlings have not been found since 1996, suggesting that much asexual reproduction takes place for this species in the area. For this species, this seems to be true of other localities along the Rio de Janeiro coastline (e.g., Zamith \& Scarano 2004).

Sampling, measurements and statistical analysis - For the anatomical analysis five leaves were collected from each of five adult individuals randomly chosen in the sun-exposed and the shaded habitat, at total of 50 samples. Fully expanded leaves, collected from the upper node, were immediately fixed in the field in formaicacetic acid-alcohol (FAA) (Berlyn \& Mishke 1976). 
Tissues were gradually dehydrated in ethanol and embedded in glycol methacrylate resin (Johansen 1940). Then, $6 \mathrm{~mm}$ transverse sections were made using a rotary microtome, and were subsequently stained with $0.1 \%$ toluidine blue and safranin (Feder \& O'Brien 1968). The following leaf anatomical parameters were measured: total leaf thickness, mesophyll thickness (spongy and palisade tissue), thickness of the outer periclinal cell wall, thickness of the adaxial and abaxial epidermis and vascular bundle transversal section area, and common epidermal cells, stomata and trichome density. In order to find out as to whether changes in number of stomata between sites were related to cell size reduction, we measured the proportion stomata:total epidermal cells. Tissue layers were quantified by using an Olympus BH2 microscope with the aid of an ocular micrometer. The proportion of sclerenchymatic area of the midrib was calculated using the image analysis program Image-Pro Plus. The video image was acquired by using a Sony video camera attached to the same optical microscope. Stomata, common epidermal cells and trichome density (number per $\mathrm{mm}^{2}$ ) were measured in a light microscope, after epidermal dissociation using Jeffrey's reagent (Jensen 1962). In order to express the variation inside and between leaves in the two populations analyzed, for each parameter described above one measurement were performed in slides of the 25 leaves collected. As a result, $\mathrm{n}=25$ for each of the parameters analysed in each population. Histochemical tests were made to identify tannins (phloroglucinol test) and calcium oxalate (chlorohydric acid) (Johansen 1940).

For morphology, quantitative data were obtained from five leaf samples collected at random from 20 individuals of each site. Leaves were placed on ice in the field and subsequently measured for saturated weight to assess leaf succulence ( $\mathrm{LS}=$ (maximum fresh weightdry weight)/area) (Mantovani 1999). Dry weight was measured after oven drying leaves for $72 \mathrm{~h}$ at $80{ }^{\circ} \mathrm{C}$. Leaf specific mass (LSM) was calculated as the ratio between blade leaf area and dry weight (Witkowski \& Lamont 1991). Later, anatomical and morphological parameters were compared statistically between sites using the Student's t-test ( $\mathrm{p}=0.05)$ (Zar 1996).

\section{Results}

In all leaves, the epidermises were single-layered in both faces. A wider variation has been observed for the adaxial than for the abaxial epidermis, including the outer periclinal cell wall. Outer periclinal cell wall nearly doubled across light extremes (Fig. 1 and 2A-B). The epidermal cells of sun-exposed leaves were thicker than those of the shaded. The outer periclinal cell walls of sun-exposed
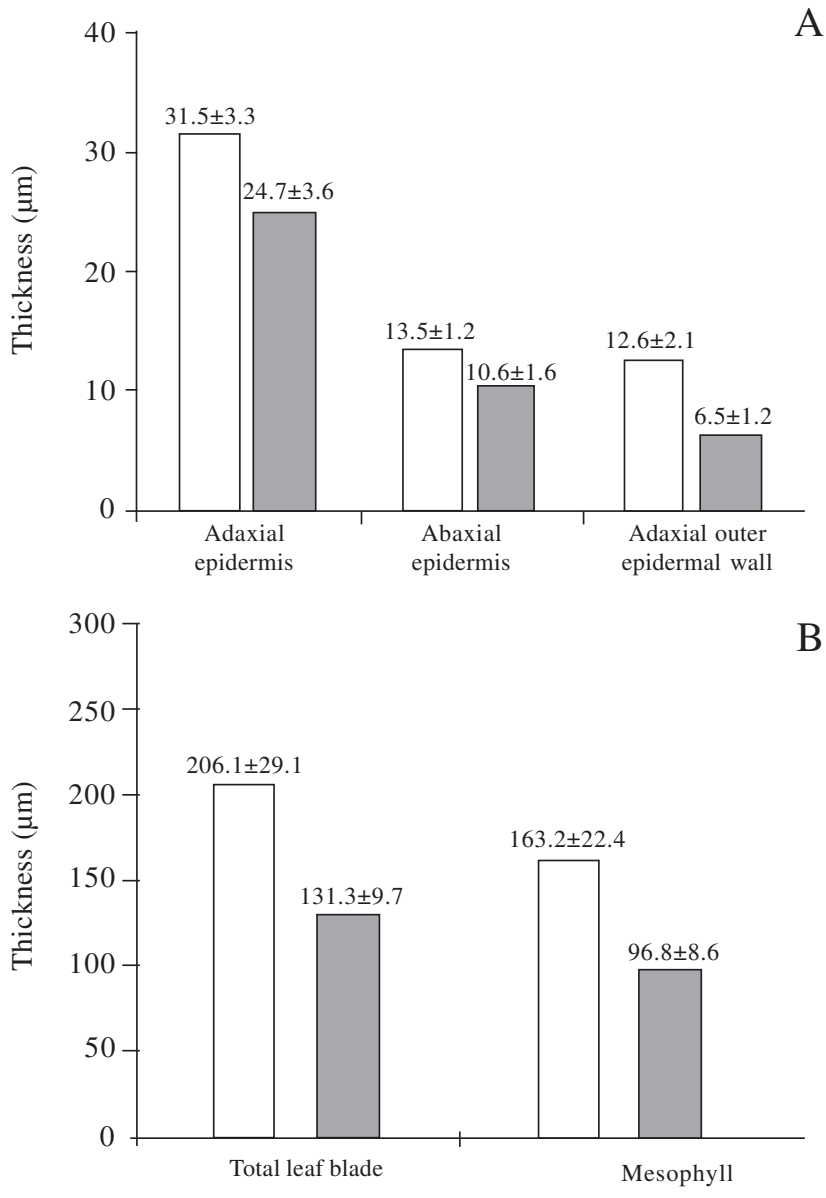

Figure 1. Leaf anatomy traits of sun-exposed (dotted bars) and shaded plants (striped bars) of Andira legalis (Vell.) Toledo ( $\mathrm{n}=25$, for each sub-population). A. Thickness of the adaxial epidermis, abaxial epidermis and adaxial outer epidermal wall. B. Total leaf blade and mesophyll thickness. Top values are mean \pm standard deviation. All values were significantly higher for the exposed plant (Student's t-test; $\mathrm{p}<0.01)$.

plants were concave whereas in shaded plants they were relatively flat (Fig. 2A-B). Moreover, epidermal cells of sun-exposed leaves showed an apparently higher tannin content than shade leaves (Fig. 2A-B). All leaves exhibited paracytic and anisocytic stomata only at the abaxial surface, characterizing hypostomatic leaves. The frequency of stomata per unit area was significantly higher in sun-exposed than in shade leaves. However, there was no difference between them for the proportion stomatal: total epidermal cells (Tab. 1). Still, at the abaxial face there were multicellular trichomes composed by a row of 3-8 cells, with the distal cell being longer than the others (Fig. 2C-D). Trichome density did not show significant differences between the two sites (Tab. 1).

In addition to the expected quantitative differences between sun-exposed and shaded leaves, A. legalis showed striking qualitative differences in the leaf anatomy. Shade plants had a dorsiventral mesophyll, with 

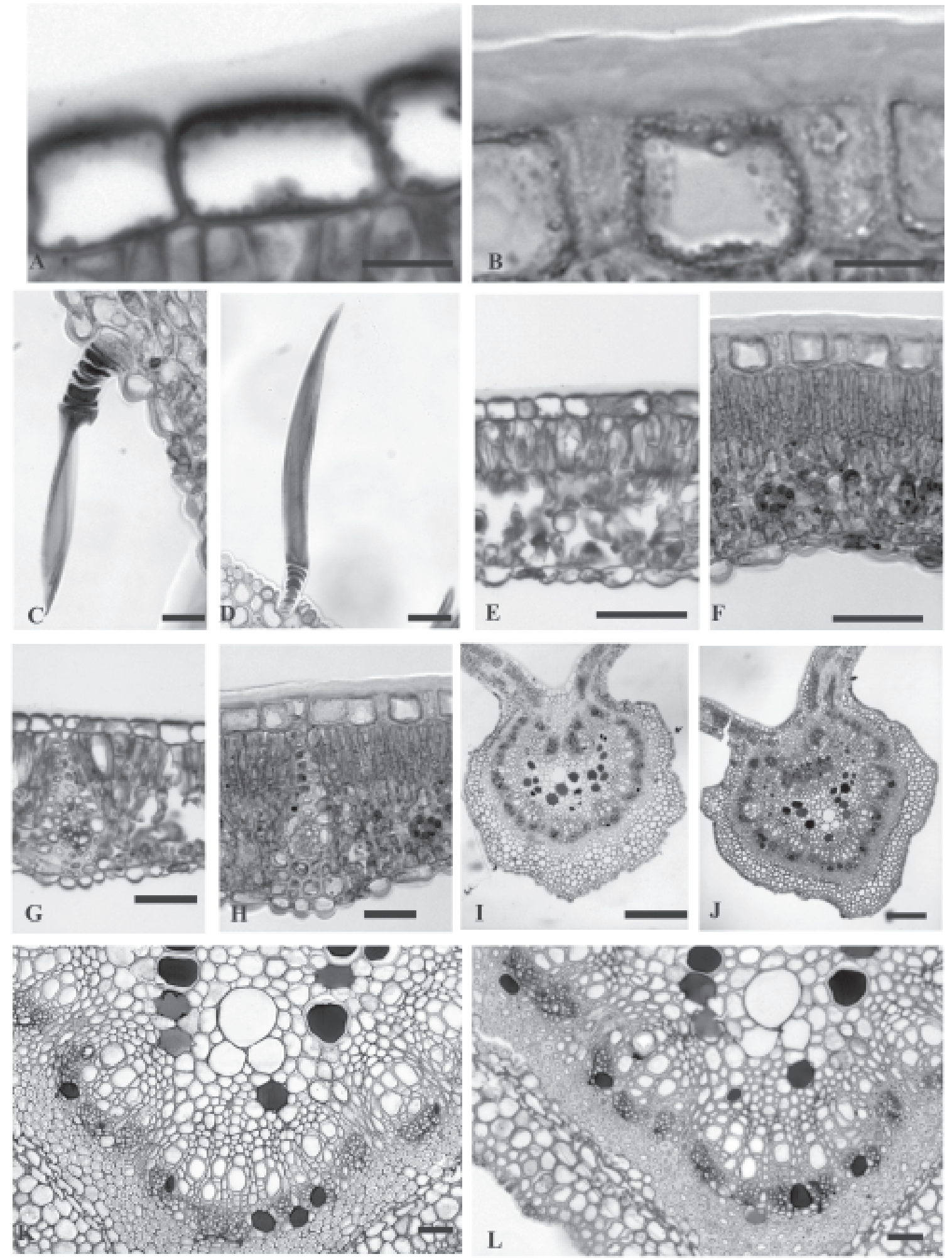

Figure 2A-L. Transverse section of the leaf of Andira legalis (Vell.) Toledo. Adaxial epidermis: A. Shaded. B. Sun-exposed. Trichome: C. Shaded. D. Sun-exposed. Leaf blade: E. Shaded. F. Sun-exposed. Collateral bundle of a vein: G. Shaded. H. Sun-exposed. Midrib: I, K. Shaded. J, L. Sun-exposed. Bars: A-B $=25 \mu \mathrm{m} ; \mathrm{C}-\mathrm{D}=20 \mu \mathrm{m} ; \mathrm{E}-\mathrm{H}, \mathrm{K}-\mathrm{L}=50 \mu \mathrm{m} ; \mathrm{I}-\mathrm{J}=100 \mu \mathrm{m}$. 
palisade parenchyma with 1 or 2 cells layers and a spongy parenchyma with 2 or 3 layers (Fig. 2E). On the other hand, the sun-exposed plants exhibited a unilateral mesophyll (Fig. 2F). Moreover, the leaves of sunexposed individuals showed higher total leaf thickness and mesophyll thickness (Fig. 1B). Changes in mesophyll thickness were apparently caused by cellular elongation and differentiation of multiple palisade layers in response to increased light. Mean leaf extension was significantly higher $(\mathrm{p}<0.05)$ in the forest $(55.9 \mathrm{~cm})$ than in the open area $(48.6 \mathrm{~cm})$.

For both sites the veins showed collateral bundles surrounded by sclerenchymatic fibres (Fig. 2G-H). Apparently, sun-exposed leaves had a higher density of veins, which could be related to the smaller leaf area in this habitat. Sheath cells were observed with extensions for both faces. In these cells, under the abaxial face, calcium oxalate crystals were identified as well as phenolic substances as tannins (Fig. 2G-H). However, the proportion of these compounds in each habitat was not measured.

A transverse section of the midrib showed an arc of collateral bundles surrounded by fibres and a sclerified parenchyma in both environments (Fig. 2I-L), however the midrib total area was significantly higher in the sunexposed leaves (Fig. 2I-J; Tab. 1). These anatomical results correlated with the leaf morphological characters measured (leaf specific mass and leaf succulence), which similarly had higher values in the sun-exposed plants.

\section{Discussion}

The clear differences in population structure, plant morphology and physiology between two sub-populations of A. legalis in this restinga ecotone (Cirne \& Scarano 2001; Scarano et al. 2001; Cirne et al. 2003; Geßler et al. 2005) are matched by a marked variation in leaf structure. The anatomical structure found in the sunexposed plants suggests a strong tendency to xeromorphism when compared with shade plants (see
Esau 1977). The direct relationship between thickness and radiation is consistent with several other studies (Strauss-Debenedetti \& Berlyn 1994; Rôças et al. 1997; Lee et al. 2000). The palisade tissue in sun-exposed leaves of A. legalis was also wider than in shade plants, which eases light penetration under direct light incidence (Vogelmann \& Martin 1993) and increases photosynthetic potential (Ashton \& Berlyn 1994; Chazdon \& Kaufmann 1993; Esau 1977; Strauss-Debenedetti \& Berlyn 1994) due to more photosynthesising cells per unit leaf area. This great structural difference between plants in adjacent localities is striking and may indicate a wide ecological plasticity of this species (see Bazzaz 1996).

The high variation observed in the outer periclinal cell wall was responsible for most of the difference found in the adaxial epidermis between the two habitats. A thicker cuticle, such as that often seen in plants of sun-exposed areas (Ashton \& Berlyn 1994), must provide a permanent biological resistance against water loss, generating low leaf water potentials protecting against desiccation during dry and windy spells (Fahn 1985; Schreiber \& Riederer 1996). The different shape of the outer periclinal cell wall between sun and shade leaves affects light distribution inside the leaf. Common epidermal cells converge diffuse light to the chlorophyllian tissue of shade leaves, and alternatively reduce direct light inside of sun-exposed leaves through reflectance reducing the risks of potential damage (Lee et al. 1990). The apparently higher tannin contents in the epidermal cells of sun-exposed leaves may act as another barrier against light penetration in these plants.

The proportion of stomatal:total epidermal cells was similar for both sites, because the higher stomatal density in sun-exposed plants was probably related to the smaller leaf size and consequently the smaller cell size when compared with shaded plants that had larger leaves. The lack of significant difference between sun-exposed and shade plants regarding leaf trichome density suggests that this trait is not related to plant acclimation to light in this species.

Table 1. Leaf anatomy and morphology parameters of Andira legalis (Vell.) Toledo (mean \pm standard deviation) of sun-exposed and shaded plants ( $n=25$, for each sub-population). MA - midrib area; SD - stomata density; S:TEC - proportion stomatal:total epidermal cells; TD - trichome density; LSM - leaf specific mass; LS - leaf succulence. *indicate significant differences at $\mathrm{p}<0.01$ (Student's t-test); NS - non-significant.

\begin{tabular}{|c|c|c|c|c|c|}
\hline & Sun & Shade & $\mathrm{t}$ & df & $\mathrm{F}$ \\
\hline MA $\left(\mathrm{mm}^{2}\right)$ & $1181.4 \pm 142.8$ & $522.7 \pm 112.6$ & 8.1 & 8 & $1.6^{*}$ \\
\hline $\mathrm{SD}$ & $549.0 \pm 62.8$ & $374.5 \pm 33.9$ & 5.5 & 8 & $3.4 *$ \\
\hline S:TEC & $14.4 \pm 2.2$ & $13.6 \pm 1.5$ & 0.02 & 8 & 0.02 NS \\
\hline $\mathrm{TD}$ & $21.4 \pm 5.4$ & $18.6 \pm 5.3$ & 0.8 & 8 & 1.07 NS \\
\hline $\operatorname{LSM}\left(\mathrm{g} \mathrm{m}^{-2}\right)$ & $169.9 \pm 12.3$ & $70.7 \pm 3.3$ & 32.1 & 38 & $13.8 *$ \\
\hline $\operatorname{LS}\left(\mathrm{g} \mathrm{m}^{-2}\right)$ & $174.3 \pm 19.6$ & $112.7 \pm 15.8$ & 10.1 & 38 & $1.5^{*}$ \\
\hline
\end{tabular}


High values observed for leaf specific mass (LSM) are often associated with concentration of structural material and formation of protective tissue for desiccation and herbivory (Choong et al. 1992; Medina et al. 1990; Turner 1994). According to Witkowski \& Lamont (1991), LSM has two components responsible for these variations: leaf density and thickness. Density is expressed by thickness of the cuticle and cell walls, extension and abundance of air spaces, and vascular bundles. In contrast, leaf thickness varies mainly with leaf shape, number of layers and length of palisade cells. Both factors may vary independently and therefore may be controlled by different environmental parameters (Niinemets et al. 1999). In A. legalis, the higher increase in the dry mass (140\%) than in thickness $(57 \%)$ in the sun-exposed leaves may suggest that leaf density could be the main factor leading to high LSM values, as found by Garnier \& Laurent (1994) for temperate grasses. In fact, this is confirmed by the very high amount of sclerenchymatic tissue of the midrib and the more densely packed mesophyll cells observed in sun-exposed leaves of A. legalis.

The increase of leaf succulence (LS) in sun-exposed plants may be related to a higher leaf thickness. Although these plants did not have a typical water parenchyma, the higher leaf volume occupied by the protoplasm of the epidermal cells and mesophyll could be responsible for the higher water storage in this organ (Garnier \& Laurent 1994; Kluge \& Ting 1978).

These results showed a high degree of variation in regard to leaf anatomy for this tree species within an ecotone, in a very small geographic area. This is in harmony with previous results regarding variation in growth, morphology and physiology for this species. The fact that in the study area the species shows a considerable contribution of asexual reproduction to plant recruitment (Cirne \& Scarano 2001) suggests that such ecological variation may take place even in a population with a possibly small genetic variability. This potential to adjust to distinct environments may explain in part the ability of this and many other Atlantic forest species to have successfully migrated in the past from a mesic forest environment to a dry, open environment such as the restingas (see Rizzini 1979; Scarano 2002). Scarano et al. (2001) investigated the ecophysiological behaviour of many Atlantic forest and restinga species and concluded that adaptation to the high light levels in the restinga habitats does not seem to have been fully achieved yet, as indicated by the commonness of chronic photoinhibition and lower energy dissipation capacity. Andira legalis, however, showed a better photosynthetic performance in exposed sites than many other woody species of the restinga (see also Geßler et al. 2005).
This could possibly be related to the efficient anatomic apparatus here described.

\section{Acknowledgements}

We thank C.G. Costa, A. Hagler, E.A. de Mattos, two anonymous referees and subject editor F.A.R. dos Santos for valuable comments on the manuscript; P. Cirne and G. Rôças for field and lab assistance; the staff at Plant Anatomy Laboratory of the Rio de Janeiro Botanical Garden for technical support; CNPq (Brazilian Research Council) and CAPES (Brazilian Agency for Graduate Studies) for research grants; and Pronex/Finep (0877) and Atlantic Forest Program (Petrobras, Brazilian Oil Company) for funding.

\section{References}

Ashton, P.M.S. \& Berlyn, G.P. 1992. Leaf adaptations of some Shorea species to sun and shade. New Phytologist 121: 587-596.

Ashton, P.M.S. \& Berlyn, G.P. 1994. A comparison of leaf physiology and anatomy of Quercus (section Erythrobalanus-Fagaceae) species in different light environments. American Journal of Botany 8: 589-597.

Bazzaz, F.A. 1996. Plants in changing environments: linking physiological, population and community ecology. Cambridge, Cambridge University Press.

Berlyn, G.P. \& Mishke, J.P. 1976. Botanical microtechique and cytochemistry. Ames, Iowa State University Press.

Chazdon, R.L. \& Kaufmann, S. 1993. Plasticity of leaf anatomy of two rain forest shrubs in relation to photosynthetic light acclimation. Functional Ecology 7: 385-394.

Choong, M.F.; Lucas, P.W.; Ong, J.S.Y.; Pereira, B.; Tan, H.T.M. \& Turner, I.M. 1992. Leaf fracture, toughness and sclerophylly: their correlations and ecological implications. New Phytologist 121: 597-610.

Cirne, P. \& Scarano, F.R. 2001. Resprouting and growth dynamics after fire of the clonal shrub Andira legalis (Leguminosae) in a sandy coastal plain in southeastern Brazil. Journal of Ecology 89: 351-357.

Cirne, P.; Zaluar, H.L.T. \& Scarano, F.R. 2003. Plant diversity, interspecific associations and postfire resprouting on a sandy spit in a Brazilian coastal plain. Ecotropica 9: 33-38.

Duarte, H.M.; Geßler, A.; Scarano, F.R.; Franco, A.C.; Mattos, E.A.; Nahm, M.; Rennenberg, H.; Rodrigues, P.J.F.P.; Zaluar, H.L.T. \& Lüttge, U. 2005. Ecophysiology of six selected shrub species in different plant communities at the periphery of the Atlantic Forest of SE - Brazil. Flora 200: 456-476.

Esau, K. 1977. Anatomía Vegetal. Barcelona, Omega.

Fahn, A. 1985. Anatomía Vegetal. Madrid, Ediciones Pirámides.

Feder, N. \& O’Brien, T.P. 1968. Plant microtechnique: some principles and new methods. American Journal of Botany 55: 123-142.

Garnier, E. \& Laurent, G. 1994. Leaf anatomy, specific mass and water content in congeneric annual and perennial grass species. New Phytologist 128: 725-736.

Geßler, A.; Duarte, H.M.; Franco, A.C.; Lüttge, U.; Mattos, E.A.; Nahm, M.; Scarano, F.R.; Zaluar, H.L.T. \& Rennenberg, H. 2005. Ecophysiology of selected tree species in different plant communities at the periphery of the Atlantic Forest of SEBrazil. II. Spatial and ontogenetic dynamics in deciduous Andira legalis. Trees 19: 510-522.

Jensen, W.A. 1962. Botanical histochemistry. San Francisco, Freeman \& Co. 
Johansen, D. 1940. Plant microtechnique. New York, McGrawHill.

Kluge, M. \& Ting, L.P. 1978. Crassulacean acid metabolism: analysis of an ecological adaptation. Berlin, Springer.

Lacerda, L.D.; Araujo, D.S.D. \& Maciel, N. C. 1993. Dry coastal ecosystems of the tropical Brazilian coast. Pp. 477-489. In: E. Van der Maarel (ed.). Dry coastal ecosystems: Africa, America, Asia and Oceania. Amsterdam, Elsevier.

Lee, D.W.; Bone, R.; Tarsis, S. \& Storch, D. 1990. Correlates of leaf optical properties in tropical forest extreme shade and sun plants. American Journal of Botany 73: 1100-1108.

Lee, D.W.; Oberbauer, S.E.; Johnson, P.; Krishnapilay, B.; Mansor, M.; Mohamad, H. \& Yap, S.K. 2000. Effects of irradiance and spectral quality on leaf structure and function in seedlings of two Southeast Asian Hopea (Dipterocarpaceae) species. American Journal of Botany 87: 447-455.

Mantovani, A. 1999. A method to improve leaf succulence quantification. Brazilian Archives of Biology and Technology 42: 9-14.

Mantuano, D.G.; Barros, C.F. \& Scarano, F.R. 2006. Leaf anatomy variation within and between three "restinga" populations of Erythroxylum ovalifolium Peyr. (Erythroxylaceae) in southeast Brazil. Revista Brasileira de Botânica 29: 209-215.

Mattos, N.F. 1979. O gênero Andira Lam. (Leguminosae Papilonoideae) no Brasil. Acta Amazonica 9: 241-266.

Medina, E.; Garcia, V. \& Cuevas, E. 1990. Sclerophylly and oligotrophic environments: relationships between leaf structure, mineral nutrients content, and drought resistance in tropical rain forest of the upper Rio Negro region. Biotropica 22: 51-64.

Niinemets, Ü.; Kull, O. \& Tenhunen, J.D. 1999. Variability in leaf morphology and chemical composition as a function of canopy light environments in coexisting deciduous trees. International Journal of Plant Sciences 160: 837-848.

Núñez-Oliveira, E.; Marínez-Abaigar, J. \& Escudero, J.C. 1996. Adaptability of leaves of Cistus ladanifer to widely varying environmental conditions. Functional Ecology 10: 636-646.

Pennington, R.T. \& Gemeinholzer, B. 2000. Cryptic clades, fruit wall morphology and biology of Andira (Leguminosae: Papilionoideae). Botanical Journal of the Linnean Society 134: $267-286$

Rizzini, C.T. 1979. Tratado de Fitogeografia do Brasil. v.2. São Paulo, Edusp.

Rôças, G.; Barros, C.F. \& Scarano, F.R. 1997. Leaf anatomy plasticity of Alchornea triplinervia (Euphorbiaceae) under distinct light regimes in a Brazilian montane Atlantic rain forest. Trees 11: 469-473.
Rôças, G.; Scarano, F.R. \& Barros, C.F. 2001. Variation in leaf anatomy of Alchornea triplinervia (Spreng.) Müll. Arg. (Euphorbiaceae) under different light and soil-water regimes. Botanical Journal of the Linnean Society 136: 231-238.

Scarano, F.R. 2002. Structure, function and floristic relationships of plant communities in stressful habitats marginal to the Brazilian Atlantic rain forest. Annals of Botany 90: 517-524.

Scarano, F.R.; Mattos, E.A.; Franco, A.C.; Herzog, B.; Ball, E.; Grams, T.E.E.; Mantovani, A.; Barreto, S.; Haag-Kerwer, A. \& Lüttge, U. 1999. Habitat segregation of C3 and CAM Nidularium (Bromeliaceae) in response to different light regimes in the understory of a swamp forest in southeastern Brazil. Flora 194: 281-288.

Scarano, F.R.; Duarte, H.M.; Ribeiro, K.T.; Rodrigues, P.J.F.P.; Barcellos, E. M.B.; Franco, A.C.; Brulfert, J.; Deléens, E. \& Lüttge, U. 2001. Four sites with contrasting environmental stress in southeastern Brazil: relations of species, life form diversity, and geographical distribution to ecophysiological parameters. Botanical Journal of the Linnean Society 136: 345-364.

Scarano, F.R.; Duarte, H.M.; Rôças, G.; Barreto, S.M.B.; Amado, E.F.; Reinert, F.; Wendt, T.; Mantovani, A.; Lima, H.R.P. \& Barros, C.F. 2002. Acclimation or stress symptom? An integrated study of intraspecific variation in the clonal plant Aechmea bromeliifolia, a widespread CAM tank-bromeliad. Botanical Journal of the Linnean Society 140: 391-401.

Scarano, F.R.; Duarte, H.M.; Franco, A.C.; Geßler, A.; Mattos, E.A.; Rennenberg, H. \& Lüttge, U. 2005. Physiological synecology of tree species in relation to geographic distribution and ecophysiological parameters at the Atlantic forest periphery in Brazil: an overview. Trees 19: 493-496.

Schreiber, L. \& Riederer, M. 1996. Ecophysiology of cuticular transpiration: comparative investigation of cuticular water permeability of plant species from different habitats. Oecologia 107: 426-432.

Strauss-Debenedetti, S. \& Berlyn, G.P. 1994. Leaf anatomical responses to light in five tropical Moraceae of different successional status. American Journal of Botany 81: 1582-1591.

Turner, L.M. 1994. Sclerophylly: primarily protective? Functional Ecology 8: 669-675.

Vogelmann, T.C. \& Martin, G. 1993. The functional significance of palisade tissue: penetration of directional versus diffuse light. Plant Cell and Environment 16: 65-71.

Witkowski, E.T.F. \& Lamont, B.B. 1991. Leaf specific mass confounds leaf density and thickness. Oecologia 88: 486-493.

Zamith, L.R. \& Scarano, F.R. 2004. Produção de mudas de espécies das Restingas do município do Rio de Janeiro, RJ, Brasil. Acta Botanica Brasilica 18: 161-176.

Zar, J.H. 1996. Biostatistical analysis. $3^{\text {rd }}$ ed. Upper Saddle River, Prentice Hall. 